\title{
TITLE:
}

\section{Circulatory CNP rescues craniofacial hypoplasia in achondroplasia(Abstract_要旨)}

$\operatorname{AUTHOR}(S)$ :

Yamanaka, Shigeki

\section{CITATION:}

Yamanaka, Shigeki. Circulatory CNP rescues craniofacial hypoplasia in achondroplasia. 京 都大学, 2017, 博士(医学)

ISSUE DATE:

2017-11-24

URL:

https://doi.org/10.14989/doctor.k20754

RIGHT:

許諾条件により本文は2018-07-24に公開 


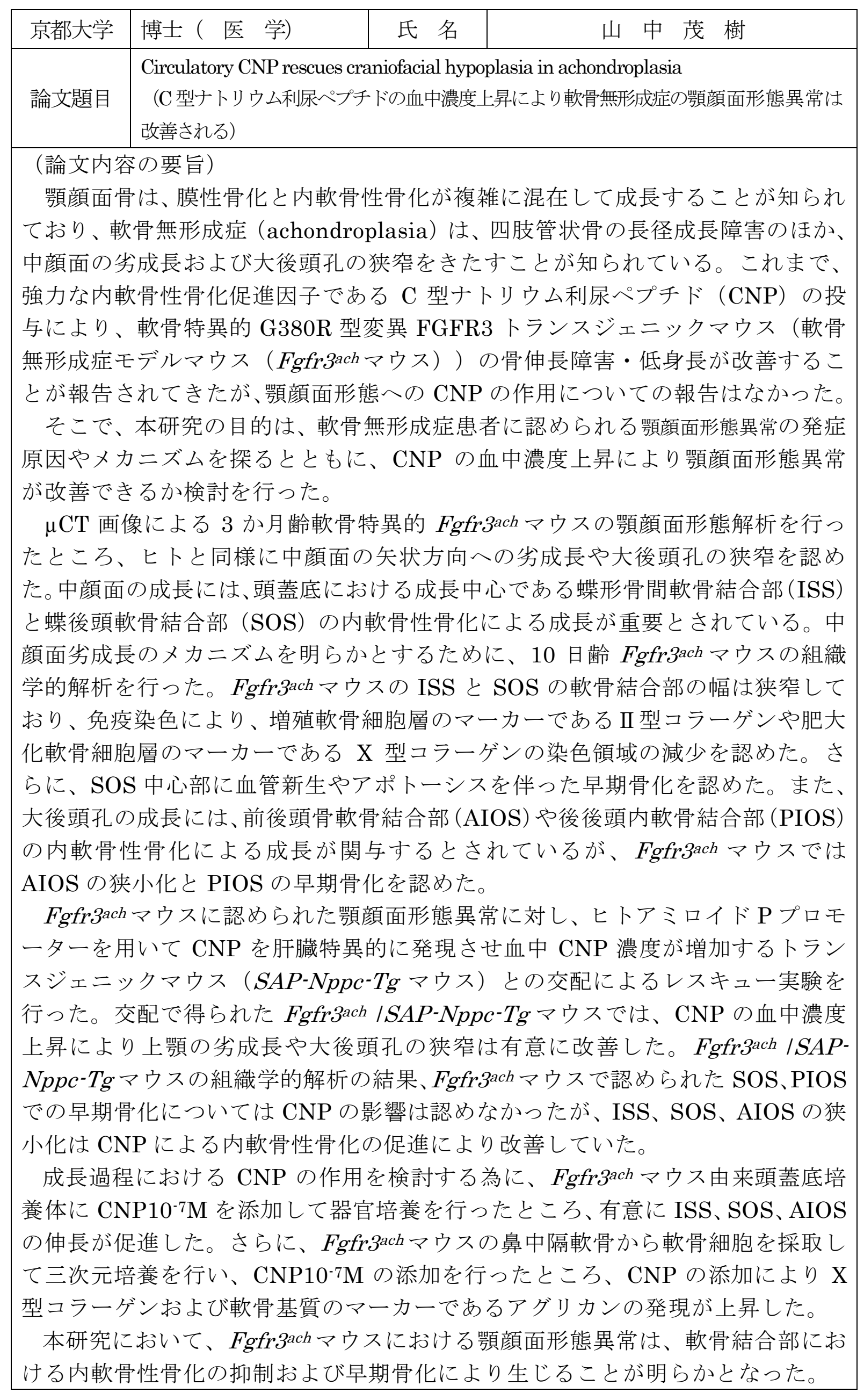

また、CNP 濃度の上昇は、顎顔面領域における軟骨結合部や鼻中隔軟骨の内軟骨性骨化 を促進させることにより、顎顔面異常を改善することが示唆された。この研究成果は、CNP 投与が軟骨無形成症など骨系統疾患を対象とした新たな治療法となりうる可能性を示唆 するものである。

\section{(論文審査の結果の要旨)}

軟骨無形成症患者に認められる顎顔面形態異常の発症原因を探るとともに、C 型ナトリ ウム利尿ペプチド (CNP) の治療における有効性について検討した。軟骨無形成症モデル マウス (Fgfr3achマウス) は、ヒトと同様に中顔面矢状方向への劣成長や大後頭孔狭窄を 認めた。Fgfr3achマウスの蝶形骨間軟骨結合（ISS）、蝶形後頭軟骨結合（SOS）、前後頭 内軟骨結合（AIOS）の狭小化を認め、SOS、後後頭内軟骨結合（PIOS）の早期閉鎖を認 めた。

Fgfr3ach マウスに認められた顎顔面形態異常に対し、ヒトアミロイド P プロモーター下 に肝臓特異的に CNP を発現させて血中 CNP 濃度が増加したトランスジェニックマウス との交配実験で得られたマウスでは、上顎の劣成長や大後頭孔の狭窄は有意に改善してい た。Fgfr3achマウスで認められた SOS、PIOS の早期閉鎖については CNP の影響を認め なかったが、ISS、SOS、AIOS の狭小化は改善された。また、Fgfr 和hマウスから採取し た組織に CNP を添加して器官培養を行ったところ、有意に ISS、SOS、AIOS の長さが 増加した。さらに、Fgfr3achマウスの鼻中隔軟骨から軟骨細胞を採取して三次元培養を行 い、CNP の添加を行ったところ、軟骨細胞の肥大化および基質産生の増大を認めた。これ により、CNP は顎顔面領域における内軟骨性骨化を促進させ、顎顔面異常を改善するこ とが示唆された。

以上の研究は、軟骨無形成症の病態の解明に貢献し、CNP が軟骨無形成症など顎顔面形 態異常をきたす疾患に対し新たな治療法となりうる可能性を示唆するものであり意義は 大きい。

したがって、本論文は博士（医学）の学位論文として価值あるものと認める。

なお、本学位授与申請者は、平成 29 年 8 月 4 日実施の論文内容とそれに関連した試問 を受け、合格と認められたものである。 